\title{
EFEKTIVITAS TEKNIK EXPRESSIVE WRITING UNTUK MERENCANAKAN KARIR PESERTA DIDIK
}

\author{
Hanifah Luthfiyah Gustini, Edy Rahman, Astoni Nurdin, Ainur Rosidah, Rega \\ Fadil Rahman \\ Universitas Muhammadiyah Pringsewu, SMK KH. Ghalib Pringsewu \\ E-mail: haniluthfiani17@gmail.com
}

\begin{abstract}
Penelitian dilatar belakangi oleh kurangnya kemampuan perencanaan karir peserta didik, yang ditandai dari banyak peserta didik yang merasakan kecemasan dalam memikirkan karirnya setelah lulus sekolah, sehingga upaya yang dilakukan yakni memberikan teknik expressive writing. Pendekatan yang digunakan adalah pendekatan kuantitatif, dan jenis penelitian pre experimental dengan desain one group pretest-postest design. Tujuan penelitian ini adalah untuk mengetahui keefektifan teknik expressive writing dalam meningkatkan perencanaan karir. Populasi berjumlah 37 siswa, dengan sampel sebanyak 15 siswa. Berdasarkan hasil penelitian didapatkan nilai (sig) 0,001 <0,05 dan z hitung sebesar 3,409 > z tabel sebesar 1,96. Hal ini ditunjukkan dengan rata-rata skor pretest 56,5 dan posttest 87,5. Hasil tersebut menunjukkan bahwa adanya peningkatan, selisih rata-rata 31 sehingga hipotesis diterima. Dengan demikian layanan informasi bidang bimbingan karir dengan teknik expressive writing terbukti efektif untuk meningkatkan perencanaan karir peserta didik.
\end{abstract}

Kata Kunci : Teknik Expressive Writing, Perencanaan Karir.

\section{PENDAHULUAN}

Bimbingan dan konseling dalam pendidikan dijadikan sebagai satuan pendidikan dalam mencerdaskan dan menggali potensi diri peserta didik. Bimbingan tidak selalu diartikan sebagai pendidikan. Namun pada saat seseorang menjalankan bimbingan, pendidikan akan selalu melekat. Pelaksanaan bimbingan yang berjalan dengan baik akan manjadi salah satu faktor utama keberhasilan kegiatan pendidikan. Maka dari itu diperlukannya guru BK yang dapat membimbing serta mengarahkan peserta didik.

Guru BK dikatakan sebagai bagian yg integral dalam pendidikan, proses pendidikan tetap akan berjalan tanpa guru BK, tetapi tanpa guru BK perkembangan karakter peserta didik tidak dapat terbentuk secara optimal. Oleh karena itu, bimbingan dan konseling telah dimasukkan dalam kurikulum sekolah. Keberadaan bimbingan dan konseling selaras dengan tujuan pembelajaran. Berada tidak hanya menyangkut transformasi ilmu pengetahuan, tetapi juga memperhatikan perkembangan peserta didik pada aspek pribadi, sosial, belajar, maupun karir.

Karir seringkali disamakan dengan pekerjaan, kemudian perencanaan karir disamakan dengan pemilihan pekerjaan. Sebenarnya arti karir lebih luas dari sekedar memilih pekerjaan. Karir berkaitan dengan perkembangan seseorang dan menjadi bagian penting dalam kesuksesan hidup seseorang, untuk itu karir perlu direncanakan dengan baik. Kemampuan perencanaan karir yang matang erat kaitannya dengan pemahaman peserta didik mengenai karir itu sendiri. 
Suksesnya pencapaian karir seseorang dipengaruhi oleh adanya kemampuan perencanaan karir dan pengambilan keputusan yang matang. Seseorang yang memiliki kemampuan perencanaan karir, tentunya mampu memahami dirinya. Dengan demikian, individu tersebut dapat memutuskan pilihan yang paling sesuai dengan keadaan dirinya.

Secara alami karir seseorang dalam hidupnya mengalami perkembangan dengan beberapa tahapan, mulai dari tahap pertumbuhan, puncak karir hingga mengalami penurunan. Berdasarkan grafik perkembangan, posisi peserta didik sekolah menengah atas sedang berada pada tahap eksplorasi, pada tahap ini peserta didik atau layak disebut remaja mulai memikirkan tentang perjalanan hidupnya setelah lulus sekolah, baik tentang pekerjaan ataupun studi lanjut. Tetapi belum mengambil keputusan yang mengikat dalam perkembangan karirnya.

Pada tahap perkembangan karir masa eksplorasi peserta didik diharapkan mampu memiliki keterampilan dalam membuat perencanaan karir. Peserta didik harus mampu memahami diri dan menilai diri, mengetahui tentang diri sendiri (sebagai dasar pengambilan keputusan karir), mengetahui bakat minat diri sendiri, mengumpulkan informasi-informasi tentang karir sampai peserta didik dapat mengidentifikasi pekerjaan atau studi lanjut yang sesuai dengan kemampuannya. Akan tetapi, kondisi demikian belum dijumpai pada peserta didik umumnya, seperti halnya yang terjadi di SMK KH. Ghalib Pringsewu.

Dari hasil fenomena yang ada, di SMK KH. Ghalib Pringsewu bimbingan dan konseling sudah ada, proses pemberian layanan bimbingan dan konseling juga sudah sering dilakukan oleh guru BK kepada peserta didik. Akan tetapi masih banyak peserta didik yang merasakan kecemasan dalam memikirkan karirnya setelah lulus sekolah. Hal tersebut terlihat dari hasil wawancara terhadap salah satu guru-guru BK SMK KH. Ghalib Pringsewu. Dari hasil wawancara tersebut dapat disimpulkan bahwa ketidakmampuan dalam merencanakan karir dengan baik pada peserta didik ditandai dengan tidak adanya kesediaan untuk mempelajari informasi karir secara mandalam, seperti tidak pernah membicarakan karir dengan orang dewasa, kurangnya pengetahuan tentang dunia luar, tidak berpatisipasi dalam kegiatan ekstrakurikuler, tidak pernah mengikuti seminar tentang pekerjaan/studi lanjut, dan kurang memadainya pengetahuan tentang persyaratan pendidikan atau studi lanjut yang diinginkan .

alam upaya memberikan pemahaman kepada peserta didik tentang perencanaan karir, maka perlu adanya kerjasama antara guru BK, wali murid serta peserta didik. Jika bentuk kerjasama ini dapat dilakukan dengan baik dari semua pihak akan dapat membantu peserta didik dalam meningkatkan kemampuan perencanaan karir yang baik. Perencanaan karir merupakan suatu aktivitas peserta didik yang mengarah pada proses perjalanan hidup selanjutnya, aktivitas perencanaan karir ini sangatlah penting bagi peserta didik terutama untuk membangun sikap peserta didik dalam menempuh karir masa depan dengan menyesuaikan minat, bakat dan potensinya.

Dalam membangun perencanaan karir, peserta didik memerlukan informasi yang berkenaan dengan karir. Dalam bimbingan konseling terdapat berbagai macam teknik dan strategi layanan. Melihat tentang kecemasan peserta didik dalam memikirkan dan merencanakan karir masa depannya, maka peneliti menggunakan teknik expressive writing yang bertujuan untuk menurunkan tingkat kecemasan dengan mengekspresikannya melalui tulisan dan untuk mengetahui kebutuhan peserta didik terkait dengan kecemasan yang dialami dalam perencanaan karirnya. 
Masalah perencanaan karir sangat penting dikaji, karena dapat memudahkan pencapaian tujuan di masa depan sehingga peserta didik yang mengalami kecemasan akan masa depannya dapat memiliki gambaran dari apa yang sudah direncanakan serta akan melakukan hal apa nantinya. Jika perencanaan karir tidak diatasi, maka akan berdampak pada masa depan peserta didik. Sesuatu yang sudah direncanakan saja terkadang tidak sesuai dengan yang diharapkan, apalagi jika sama sekali tidak mempunyai perencanaan untuk hari esok yang disebut masa depan. Berdasarkan uraian tersebut, maka penting untuk dilakukan pengkajian lebih mendalam apakah pemberian teknik expressive writing efektif untuk merencanakan karir peserta didik.

\section{METODE PENELITIAN}

Pendekatan yang digunakan dalam penelitian ini adalah pendekatan kuantitatif, jenis penelitian pre experimental dengan desain one group pretest-postest design. Setelah memberikan pretest yang diberikan sebelum peneliti membuat perlakuan berupa layanan informasi bidang bimbingan karir, peneliti memberikan teknik expressive writing kepada peserta didik, selanjutnya peneliti memberikan posttest yang diberikan setelah peneliti memberikan teknik expressive writing serta memberikan pemahaman tentang perencanaan karir atau treatment kepada peserta didik. Dengan demikian, hasil perlakuan dapat diketahui lebih tepat karena dapat membandingkan keadaan sebelum dan sesudah dilakukan perlakuan.

Untuk mempermudah responden dalam menjawab suatu pernyataan dalam angket/kuesioner, peneliti menggunakan skala likert. Skala likert ini digunakan untuk mengukur sikap, pendapat, persepsi seseorang tentang gejala atau masalah yang ada (Aziz 2010:102). Berdasarkan jawaban responden pada instrumen yang disebarkan nantinya didapatkan skor pengkategorian untuk mengetahui sejauh mana perencanaan karir peserta didik. Validitas yang dipergunakan peneliti adalah validitas isi, dengan satu alasan bahwa variabel yang ada diuraikan atau dijabarkan menjadi sub-sub variabel atau indikator, kemudian dari indikator dijabarkan kembali ke dalam item atau instrumen penelitian dengan berdasarkan pada konsep-konsep teoritis yang ada (Sujarweni: 2014). Untuk menguji tingkat tingkat validitas item (butir) angket, peneliti menggunakan program SPSS 20.0 for windows, dengan rumus korelasi product moment.

Dalam penelitian ini menggunakan tarif signifikan $r$ tabel dengan signifikan 0,30. Bila korelasi tiap butir positif dan besarnya 0,30 ke atas maka butir tersebut merupakan construct yang kuat (Sugiyono, 2016). Dengan ketentuan apabila korelasi setiap item lebih besar dari 0,30 maka item tersebut valid dan apabila korelasi item lebih kecil dari 0,30 maka item tersebut tidak valid.

Reliabilitas diukur dengan cara, peneliti menggunakan pengujian internal dengan teknik test retest. Dalam teknik ini, instrumen penelitian dicobakan beberapa kali pada responden yang sama dengan instrumen yang sama dalam waktu berbeda. Reliabilitas diukur dari koefisien korelasi antara percobaan pertama dengan yang berikutnya. Bila koefisien korelasi positif dan signifikan, maka instrumen penelitian sudah dinyatakan reliabel. Pengujian reliabilitas internal ini dilakukan dengan menggunakan rumus Alpha Cronbach $(\alpha)$ dalam program SPSS versi 20 for windows.

\section{HASIL DAN PEMBAHASAN}

Dalam penelitian ini, pengumpulan data yang dilakukan oleh peneliti yaitu dengan melakukan observasi dan wawancara kepada guru BK di SMK KH. Ghalib Pringsewu. Selanjutnya peneliti menyebarkan instrumen kepada responden sebagai try out dengan tujuan untuk 
mengetahui validitas dan reliabilitas alat ukur (instrumen). Diuji cobakan pada sampel berukuran kecil $(\mathrm{N}= \pm 20)$ orang reponden untuk memeriksa apakah kalimat yang digunakan sudah dimengerti dan dipahami seperti kehendak peneliti.

Selanjutnya peneliti melakukan pretest, yaitu pengukuran atau penilaian (dengan mengisi instrumen perencanaan karir) kepada populasi penelitian yang berjumlah 37 peserta didik, sebelum diberikan teknik expressive writing dan perlakuan yang berupa layanan informasi bidang bimbingan karir untuk menentukan sampel.

Setelah melakukan pretest, peneliti menentukan sampel menggunakan teknik purposive sampling dengan pertimbangan atau kriteria peserta didik yang termasuk dalam kategori perencanaan karir rendah. Untuk mengetahui tingkat pemahaman responden dalam perencanaan karir dan untuk membantu peserta didik dalam merencanakan karir masa depan.

Selanjutnya setelah pelaksanaan teknik expressive writing selesai, peneliti memberikan beberapa layanan informasi bidang bimbingan karir atau dapat disebut treatment, dibagi menjadi empat sesi pertemuan dengan pokok pembahasan sebagai berikut:

\section{Sesi Pertama}

Pelaksanaan sesi pertama dilakukan pada hari Selasa, 02 Februari 2021. Peneliti memberikan layanan yang berjudul "Karir Berbasis Pendidikan dan Pekerjaan". Tujuannya agar peserta didik mampu memahami tentang karir yang konteks pembahasannya mengarah pada pendidikan dan pekerjaan. Sesi ini dilakukan setelah pelaksanaan teknik exprssive writing, sesuai hasil dari menulis bebas terkait perencanaan karir (teknik expressive writing).

2. Sesi Kedua

Pelaksanaan sesi kedua dilakukan pada hari Rabu, 03 Februari 2021. Peneliti memberikan layanan yang berjudul "Menentukan Kondisi Pekerjaan". Tujuan sesi ini adalah agar peserta didik mengerti dan mengetahui bagaimana cara mencapai sukses yang konteks pembahasannya mengarah pada kondisi suatu pekerjaan seusai tamat sekolah.

\section{Sesi Ketiga}

Pelaksanaan sesi ketiga dilakukan pada hari Selasa, 09 Februari 2021. Peneliti memberikan layanan yang berjudul "Bidang Minat Jurusan di Perguruan Tinggi". Tujuan sesi ini adalah agar peserta didik dapat memahami dan mengetahui kekuatan dan kelebihan diri guna menentukan cita-cita untuk melanjutkan study dengan memberikan beberapa contoh karakter agar peserta didik dapat menganalisis serta menilai minat yang dimiliki untuk memilih jurusan di Perguruan Tinggi.

\section{Sesi Keempat}

Pelaksanaan sesi keempat dilakukan pada hari Rabu, 10 Februari 2021. Peneliti memberikan layanan yang berjudul "Belajar Merencanakan Masa Depan". Tujuan sesi ini adalah agar peserta didik dapat merencanakan serta mempersiapkan masa depannya sejak dini.

Kemudian setelah pemberian layanan selesai, peneliti memberikan kuesioner yang sama untuk kedua kalinya (posttest) kepada sampel penelitian. Berikut hasil grafik pretest dan posttest

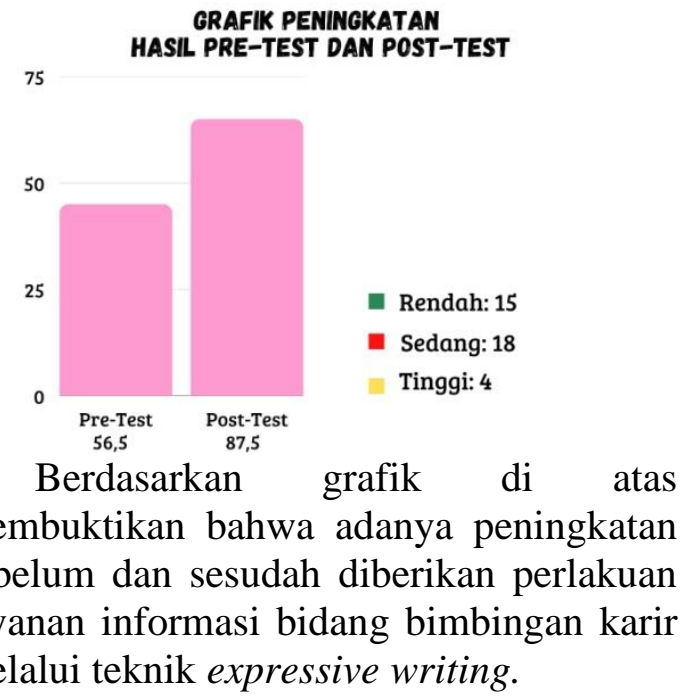


Expressive writing merupakan salah satu intervensi berbentuk psikoterapi kognitif yang dapat mengatasi masalah depresi, cemas, dan setres, karena terapi ini merupakan terapi perefleksian pikiran dan perasaan terdalam terhadap peristiwa yang tidak menyenangkan. Expressive writing dapat digunakan sebagai terapi utama dalam menurunkan kecemasan (Danarti, Dkk: 2018).

Dalam hal ini penelitian yang dilakukan oleh peneliti sajalan dengan pendapat ahli tersebut yaitu menggunakan cara menulis untuk merencanakan karir, karena dengan menulis peserta didik dapat mengeksplorasi dan lebih bebas dalam mengekspresikan perasaan cemas yang dialaminya dalam memikirkan serta merencanakan karir masa depan yang diinginkan. Karir adalah keseluruhan pekerjaan yang pernah dijalani atau dimiliki seseorang selama hidupnya. Karir merupakan rangkaian pekerjaan yang berhubungan dengan pengalaman, serta kegiatan selama individu tersebut bekerja (Nurdin \& Saleh, 2018). Sementara Gibson (dalam Kartono, 2009:304) mengatakan bahwa karir adalah serangkaian perasaan individual dari sikap dan perilaku yang berkaitan dengan pengalaman kerja dan aktivitas selama rentang waktu dalam kehidupan seseorang.

Karir seseorang dalam hidupnya mengalami perkembangan dengan beberapa tahapan, posisi peserta didik sekolah menengah atas sedang berada pada tahap eksplorasi, pada tahap ini peserta didik atau layak disebut remaja mulai memikirkan tentang perjalanan hidupnya setelah lulus sekolah, baik tentang pekerjaan ataupun studi lanjut, tetapi belum mengambil keputusan yang mengikat dalam perkembangan karirnya. Pada tahap perkembangan karir masa eksplorasi peserta didik diharapkan mampu memiliki keterampilan dalam membuat perencanaan karir. Peserta didik harus mampu memahami diri dan menilai diri, mengetahui tentang diri sendiri (sebagai dasar pengambilan keputusan karir), mengetahui bakat minat diri sendiri, mengumpulkan informasi-informasi tentang karir sampai peserta didik dapat mengidentifikasi pekerjaan atau studi lanjut yang sesuai dengan kemampuannya. Dengan masa eksplorasi sesuai dengan usia peserta didik yang dijadikan responden, maka sangat tepat untuk usia eksplorasi atau remaja dalam meningkatkan perencanaan karirnya.

Keefektifan teknik expressive writing dapat dilihat pada nilai (sig) 0,001 lebih kecil dari 0,05 dan z hitung sebesar 3,409 lebih besar dari z tabel sebesar 1,96. Hal ini ditunjukkan dengan hasil kuesioner perencanaan karir diperoleh dengan ratarata skor pretest 56,5 dan rata-rata skor posttest sebesar 87,5. Ini menunjukkan bahwa adanya perkembangan rata-rata skor sebelum dan sesudah diberikan perlakuan dengan selisih rata-rata 31 sehingga hipotesis diterima. Dengan demikian, pemberian teknik expressive writing efektif untuk merencanakan karir peserta didik di SMK KH. Ghalib Pringsewu.

\section{KESIMPULAN}

Berdasarkan keseluruhan proses penelitian dan deskripsi data penelitian yang diperoleh, dapat disimpulkan bahwa layanan informasi bidang bimbingan karir dengan teknik expressive writing efektif untuk meningkatkan perencanaan karir peserta didik. Hal ini dapat dilihat dari penghitungan menggunakan stastistik non parametric yaitu dengan wilcoxon signed rank test yang menunjukan hasil meningkat. Berikut merupakan hasil layanan informasi bidang bimbingan karir dengan teknik expressive writing, yaitu:

1. Perubahan pengetahuan peserta didik yang lebih memahami tentang karir, mempelajari informasi karir secara mandalam, tidak lagi kekurangan pengetahuan tentang dunia luar, lebih memiliki pengetahuan tentang 
persyaratan pendidikan atau studi lanjut yang diinginkan, dan dapat merencanakan karir masa depannya.

2. Peningkatan skor rata-rata, dibuktikan dengan perolehan rata-rata pada hasil skor prettest 56,5 dan setelah memberian layanan informasi bidang bimbingan karir dengan teknik expressive writing diperoleh skor ratarata posttest 87,5.

3. Menunjukan peningkatan rata-rata skor dari pretest ke posttest selisih rata-rata skor sebesar 31 sehingga dapat disimpulkan bahwa hipotesis diterima.

Berdasarkan hasil yang telah diperoleh, terjawablah sebuah hipotesis bahwa pemberian teknik expressive writing efektifuntuk merencanakan karir peserta didik kelas XI TKJ 2 SMK KH. Ghalib Pringsewu.

\section{REFRENSI}

Aziz A,H. (2013). Metode Penelitian Kebidanan dan Teknik Analisis Data. Jakarta: Salemba Medika

Batjo Nurdin, dan Mahidin Shaleh. (2018). Manajemen Sumber Daya Manusia. Makassar: Aksara Timur.

Danarti, N. S, Angga Sugiarto, dan Sunarko. (2018). "Pengaruh Expressive Writing Therapy Terhadap Penurunan Depresi, Cemas, dan Setres pada Remaja". Jurnal Ilmu Keperawatan Jiwa Volume 1 No 1. Hal 48-61.

Kartono. (2009). Kepribadian dan Politik Bank Perkreditan Rakyat. Yogyakarta: CV Budi Utama.

Sugiyono. (2016). Metode Penelitian Pendidikan (Pendekatan Kuantitatif, Kualitatif dan $R \& D)$. Bandung: ALFABETA.
Sujarweni, V.W. (2014). Metodologi Penelitian.Yogyakarta:Pustaka baru press 